УДК 616:126-002-022:616.12-053.2]-089.168

\title{
Віддалені результати хірургічного лікування інфекційного ендокардиту у дітей із вродженими вадами серця
}

\author{
Прокопович Л. М., Головенко О. С., Руденко М. М., Списаренко С. П., \\ Малишева Т. А., Труба Я. П., Лазоришинець В. В.
}

ДУ «Національний інститут серцево-судинної хірургії імені М. М. Амосова НАМН» (Київ)

\begin{abstract}
У роботі представлено віддалені результати хірургічного лікування інфекційного ендокардиту (IE) у дітей із вродженими вадами серця (ВВС). За період з січня 2007 по грудень 2017 рік в ДУ «НІССХ імені М. М. Амосова НАМН» було прооперовано 32 дитини з IE на фоні ВВС. Середній вік пацієнтів на момент операції становив $11,6 \pm 5,7$ років. Госпітальна летальність склала $6,2 \%$ (два пацієнти). У віддалені строки після хірургічного втручання обстежено 28 пацієнтів - 93,3\% виписаних на госпітальному етапі. Період спостереження тривав від п'яти місяців до 10,1 років $(5,9 \pm 2,5$ років). Вік пацієнтів на момент обстеження варіював від 2,1 до 24,3 років $(17,1 \pm 7,8)$. У віддаленому періоді померло два пацієнти $(7,1 \%)$. За даними аналізу (Kaplan-Meier), показник кумулятивної виживаності хворих через 1 рік після операції склав 100\%, через 5 років - 96,2\%, через 10 років - 90,2\%. У двох $(7,1 \%)$ клінічних випадках були повторно виявлені ознаки IE. Показник частки пацієнтів без повторних операцій у віддаленому періоді спостереження через 1 рік склав $92,6 \%$, через 5 років - $84,2 \%$, через 10 років $-77,2 \%$.
\end{abstract}

Ключові слова: інфекційний ендокардит, хірургічне лікування, вроджені вади серия, віддалені результати.

IE зустрічається у дітей відносно рідко, проте є серйозною інфекцією, яка потенційно супроводжується значною захворюваністю та смертністю [1, 2]. Це пов'язують зі збільшенням кількості операцій при ВВС, нозокоміальними чинниками, постійним розширенням спектра інвазивних діагностичних і лікувальних медичних маніпуляцій.

За даними Rosenthal L. B., частіше хворіють діти віком від одного місяця до одного року і від 12 років. За останнє десятиліття значно змінилися демографічні показники в даній категорії пацієнтів: середній вік дітей знизився в середньому з 8 до 1,5 років. Збільшилася кількість пацієнтів, які перенесли кардіохірургічні втручання [2].

Незважаючи на успіхи сучасної медицини в галузі медикаментозної терапії, загальна летальність хворих із ВВС при IЕ становить 18-20\% [3]. Ефективність хірургічного лікування стала більш ніж очевидною при порівнянні показників летальності: після проведеного оперативного лікування при IE госпітальна летальність знизилася до 3-8\% [4].

Проблема IE у дітей із ВBC є надзвичайно актуальною, оскільки наявність ВВС - це не тільки фактор ризику IE, а й окрема ланка патогенезу, яка перешкоджає вилікуванню медикаментозними методами. Локалізація ушкодження пов'язана з гемодинамічним ефектом високого градієнту тиску на рівні звуженого отвору - такого, як септальний дефект, стенозований клапан, звужена ділянка магістральної судини, кон- дуїту або камери серця. Наявність ВВС призводить до формування турбулентного потоку крові, який ушкоджує ендокард та ендотелій магістральних судин, що створює сприятливі умови для розвитку асептичного тромбоендокардиту, а потім IE [5].

У пацієнтів з некорегованими ВВС загальний ризик ендокардиту знаходиться в межах від 0,1 до $0,2 \%$ на пацієнта в рік і знижується до $0,02 \%$ після корекції вади. Найбільший ризик мають пацієнти зі складними ВВС «синього типу» [6].

Наявність ВВС є суттєвою відмінністю між дорослим і дитячим населенням і впливає на епідеміологію, лікування та наслідки IE [7]. Хоча рекомендації щодо хірургічного лікування IE були представлені American Heart Association та схвалені American Academy of Pediatrics, вони визначалися за показниками дорослого населення і можуть виявитися неприйнятними для дітей [8]. Результати, що підтверджують досвід хірургічного лікування дітей, рідкісні, тому на сьогоднішній день немає рандомізованих досліджень щодо показань до хірургічного лікування IE у педіатричної групи. Раннє хірургічне втручання під час гострої фази інфікування було пов'язане з добрими результатами у дорослих [9-10]. Це наводить на думку, що, ймовірно, встановлення оптимального терміну втручання має вирішальне значення для покращення результатів хірургічного лікування у дітей.

Мета роботи - провести аналіз віддалених результатів хірургічного лікування при IЕ у дітей із ВBC. 
Таблиця 1

Тривалість захворювання до операції

\begin{tabular}{ccc}
\multirow{2}{*}{$\begin{array}{c}\text { Tривалість захворювання, } \\
\text { місяці }\end{array}$} & \multicolumn{2}{c}{$\begin{array}{c}\text { Загальна кількість хворих } \\
\mathbf{n = 3 2}\end{array}$} \\
\hline$<1$ & $\mathbf{n}$ & $\mathbf{\%}$ \\
\hline $1-3$ & 3 & 9,4 \\
\hline $3-6$ & 14 & 43,8 \\
\hline$>6$ & 10 & 31,2 \\
\hline Всього & 5 & 15,6 \\
\hline & $\mathbf{3 2}$ & $\mathbf{1 0 0}$
\end{tabular}

Матеріали та методи. Із січня 2007 по грудень 2017 p. в ДУ НІССХ імені М. М. Амосова було прооперовано 32 дитини з ВBC, ускладненими IЕ. Пацієнтів чоловічої статі було $21(65,7 \%)$, жіночої - $11(34,3 \%)$. Середній вік пацієнтів на момент операції склав $11,6 \pm 5,7$ років (від 2 тижнів до 18 років). Більшість хворих були направлені в кардіохірургічний стаціонар після безуспішного та тривалого лікування в педіатричних стаціонарах. При аналізі перебігу захворювання оцінювали час тривалості хвороби на момент виконання операції (табл. 1). Тривалість захворювання склала

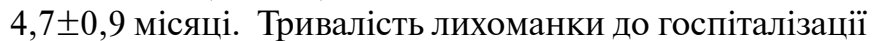
становила 9,6 6 7,3 тижні. У 15 (46,9\%) випадках операція була виконана за екстреними показаннями: у зв'язку з наявністю тромбоемболії ЛА - 3 пацієнти, з масивними вегетаціями із загрозою відриву -6 випадків, з абсцесом фіброзного кільця аортального клапана (AК) -5 випадків, з гострим порушенням мозкового кровообігу - 1 випадок. Оцінка стану пацієнтів перед операцією за NYHА показала, що в IV функціональному класі (ФК) NYHА перебували 7 пацієнтів (21,9\%\%), в III ФК - $14(43,7 \%)$, в II ФК - $11(34,3 \%)$.

При поступленні в клініку встановлювався характер ВBC, наявність ускладнень і супутніх захворювань, проводилась ідентифікація виду мікроорганізмів та їх чутливості до антибактеріальних препаратів, а також визначалися показання до оперативного втручання. Розподіл пацієнтів за типом ВВС представлено в табл. 2.

У досліджуваній групі збудник виявлено у 23 (71,9\%) випадках (табл. 3): грампозитивна флора $\mathrm{n}=18(78,3 \%)$, грамнегативні збудники $-\mathrm{n}=2(8,7 \%)$, грибкова інфекція $-\mathrm{n}=3$ (13\%).

Ймовірними провокуючими факторами були хронічні інфекційні захворювання шкіри та підшкірножирової клітковини (геморагічний васкуліт) у трьох $(9,4 \%)$ пацієнтів, хронічні запальні захворювання верхніх і нижніх дихальних шляхів у $19(59,4 \%)$ випадках, інвазивні стоматологічні процедури у двох $(6,2 \%)$ хворих, інфікована травма при значних опіках тіла в одному $(3,1 \%)$ випадку, попередні кардіохірургічні

\section{Таблиця 2}

Розподіл пацієнтів за діагнозами

\begin{tabular}{lcc} 
& \multicolumn{3}{c}{ Загальна кількість } \\
хворих & $\mathbf{n}=\mathbf{3 2}$ \\
Діагноз & $\mathbf{n}$ & \% \\
Дефект міжшлуночкової перегородки & 12 & 37,5 \\
Дефект міжшлуночкової перегородки, & 2 & 6,2 \\
стеноз легеневої артерії & 1 & 3,1 \\
Субаортальний стеноз & 1 & 3,1 \\
Субаортальний стеноз, розшаровуюча & 1 & 3,1 \\
аневризма висхідної аорти & 1 & 3,1 \\
Стеноз легеневої артерії (клапанний) & 2 & 6,2 \\
Коарктація аорти & & \\
Стан після радикальної корекції тетради & \\
Фалло & 1 & 3,1 \\
Стан після пластики дефекту & 1 & 3,1 \\
міжшлуночкової перегородки & 10 & 31,2 \\
Тетрада Фалло &
\end{tabular}

втручання у п'ятьох $(15,6 \%)$ пацієнтів. Слід зазначити, що у $15(46,9 \%)$ пацієнтів, які перебували на стаціонарному лікуванні в медичних закладах, виконувалася катетеризація центральних вен.

На доопераційному етапі всім пацієнтам було проведено повне клінічне обстеження. Діагноз інфекційного ендокардиту встановлювався згідно з модифікованими критеріями Duke [11-12]. Враховуючи високу діагностичну цінність трансторакального ехокардіографічного (ЕхоКГ) дослідження, його виконували у $100 \%$ випадків. Основними ЕхоКГ-критеріями для постановки діагнозу були: наявність вегетацій, клапанна недостатність, паравальвулярні абсцеси. У 11 (34,4\%) випадках для уточнення діагнозу використовували трансстравохідне дослідження. ЕхоКГ-ознаками IE були: вегетації $-\mathrm{n}=32$ (100\%), абсцеси $-\mathrm{n}=9(28,1 \%)$, перфорації стулок клапанів - n=10 $(31,2 \%)$.

Основними показаннями до оперативного лікування були: прогресуюча серцева та клапанна недо-

\section{Таблиця 3}

Мікробіологічний спектр збудників інфекційного ендокардиту

\begin{tabular}{lcc} 
& \multicolumn{2}{c}{ Кількість хворих $\mathbf{( n = 2 3 )}$} \\
\cline { 2 - 3 } Збудник & $\mathbf{n}$ & $\mathbf{\%}$ \\
\hline Staphylococcus aureus & 8 & 34,9 \\
\hline Staphylococcus epidermidis & 4 & 17,4 \\
\hline Streptococcus viridans & 3 & 13,0 \\
\hline Enterococcus faecalis & 3 & 13,0 \\
\hline Klebsiella pneumoniae & 2 & 8,7 \\
\hline Candida albicans & 3 & 13,0
\end{tabular}




\section{Таблиця 4}

Види оперативних втручань

\begin{tabular}{|c|c|c|}
\hline \multirow[b]{2}{*}{ Оперативні втручання } & \multicolumn{2}{|c|}{$\begin{array}{c}\text { Загальна } \\
\text { кількість } \\
\text { втручань } \\
\text { n=32 }\end{array}$} \\
\hline & $\mathbf{n}$ & $\%$ \\
\hline \multicolumn{3}{|l|}{ Пластика ДМШП: } \\
\hline $\begin{array}{l}\text { - з пластикою тристулкового клапана (ТК) + } \\
\text { видалення вегетацій з ДМШП та ТК: }\end{array}$ & 5 & 15,6 \\
\hline - з видаленням вегетацій із ТК: & 7 & 21,9 \\
\hline $\begin{array}{l}\text { - } з \text { пластикою ВТПШ, видаленням вегетацій із ТК, } \\
\text { ДМШП, клапана ЛА: }\end{array}$ & 1 & 3,1 \\
\hline $\begin{array}{l}\text { - із закриттям відкритої артеріальної протоки, } \\
\text { усуненням стенозу ЛА та видаленням вегетацій } \\
\text { зі стовбура ЛА: }\end{array}$ & 1 & 3,1 \\
\hline \multicolumn{3}{|l|}{ Протезування АK: } \\
\hline $\begin{array}{l}\text { - з усуненням субаортального стенозу, видален- } \\
\text { ням вегетацій з АК та пластикою абсцесу аорти } \\
\text { аутоперикардіальною латкою: }\end{array}$ & 1 & 3,1 \\
\hline $\begin{array}{l}\text { - з видаленням вегетацій з АК та усуненням } \\
\text { абсцесу кореня аорти: }\end{array}$ & 4 & 12,5 \\
\hline $\begin{array}{l}\text { - з пластикою ДМШП, видаленням вегетацій з } \\
\text { АК, мітрального клапана (МК) та ТК, пластикою } \\
\text { абсцесу кореня аорти, пластикою МК, пласти- } \\
\text { кою ТК: }\end{array}$ & 1 & 3,1 \\
\hline - з пластикою МК та видаленням вегетацій з МК: & 2 & 6,2 \\
\hline $\begin{array}{l}\text { - операція Ferazzi, пластика MK, усунення абсце- } \\
\text { су кореня аорти: }\end{array}$ & 1 & 3,1 \\
\hline \multicolumn{3}{|l|}{ Пластичні операції на АК: } \\
\hline $\begin{array}{l}\text { - пластика АК аутоперикардіальною латкою, } \\
\text { видалення вегетацій з АК: }\end{array}$ & 1 & 3,1 \\
\hline $\begin{array}{l}\text { - аортальна вальвулотомія, видалення вегетацій } \\
\text { з правої коронарної стулки АК: }\end{array}$ & 1 & 3,1 \\
\hline $\begin{array}{l}\text { Операція Росса, видалення вегетацій з МК, } \\
\text { пластика МK }\end{array}$ & 2 & 6,2 \\
\hline $\begin{array}{l}\text { Усунення субаортального стенозу та } \\
\text { пластика аневризми висхідної аорти } \\
\text { аутоперикардіальною латкою }\end{array}$ & 1 & 3,1 \\
\hline $\begin{array}{l}\text { Радикальна корекція ТФ, видалення вегетацій зі } \\
\text { стовбура та гілок ЛА }\end{array}$ & 1 & 3,1 \\
\hline $\begin{array}{l}\text { Усунення клапанного стенозу ЛА, видалення } \\
\text { вегетацій та пластика ЛА }\end{array}$ & 1 & 3,1 \\
\hline $\begin{array}{l}\text { Видалення вегетацій з АК, МК, МШП, } \\
\text { пластика МК }\end{array}$ & 1 & 3,1 \\
\hline $\begin{array}{l}\text { Видалення вегетацій з ТК та пластика ТК після } \\
\text { рентген-ендоваскулярної дилатації КА }\end{array}$ & 1 & 3,1 \\
\hline
\end{tabular}

статність на фоні внутрішньосерцевих порушень гемодинаміки, наявність тромбоемболічних ускладнень в артеріях малого та великого кола кровообігу, масивні вегетації із загрозою відриву, абсцеси фіброзного кільця, некореговані ВВС та реканалізація оперованих раніше внутрішньосерцевих дефектів на фоні інфекційного процесу.

Всі оперативні втручання виконувалися із серединного доступу, в умовах штучного кровообігу, фармакохолодової кардіоплегії та помірної гіпотермії (табл. 4). Тривалість штучного кровообігу становила $132,4 \pm 17,5$ хв., час перетискування аорти $-84,3 \pm 13,7$ хв. Обов'язковим компонентом усіх операцій при IE була механічна та хімічна санація камер серця. Під час операції висікали всі ушкоджені тканини, матеріал відправляли для бактеріологічного та гістологічного дослідження. Проводили ревізію всіх уражених ділянок серця з метою виявлення та усунення можливих вогнищ інфекції. Абсцеси було виявлено у 9 пацієнтів: абсцес кореня аорти - у 7 пацієнтів (в одному спостереженні поєднувався з мікотичною аневризмою аорти), абсцес клапана ЛА - у 2 випадках.

Повторні хірургічні втручання виконано у чотирьох пацієнтів. У клапанному апараті при IE найбільш часто був ураженим ТK - у 15 (46,9\%) пацієнтів, що у 7 випадках потребувало виконання пластичних операцій на клапані. Вегетації на АК були виявлені у 14 випадках $(43,7 \%)$ і поєднувалися з абсцесом кореня аорти у семи випадках. Ушкодження АК зустрічалися у вигляді розриву, перфорації або відриву стулок від фіброзного кільця. У зв'язку з пізнім зверненням хворих у хірургічний стаціонар і вираженою деструкцією клапанного апарату переважали втручання з імплантацією штучних механічних протезів $-\mathrm{n}=9(28,1 \%)$. В одному випадку вдалося виконати відкриту аортальну вальвулотомію із санацією стулок клапана і аорти. У двох пацієнтів виконали операцію Росса. Пластичні операції на МК у зв'язку з наявністю вегетацій було виконано у 7 пацієнтів.

Серед неклапанних уражень відмічалися вегетації пристінкового ендокарда і ендотелію магістральних судин, інфіковані ерозії та тромби. Найбільш часто такі ураження розвивалися у хворих із ДМШП - 7 пацієнтів, клапанним і підклапанним стенозом ЛА - 3 пацієнти, субаортальним стенозом - 2 пацієнти, ТФ - 1 пацієнт. У двох випадках інфекція розвинулася у пацієнтів, яким раніше була виконана радикальна корекція ТФ, і супроводжувалася решунтуванням ДМШП. Дана когорта $€$ найбільш складною серед всіх пацієнтів з IE, оскільки кожна ВВС потребує індивідуального хірургічного підходу.

Результати та обговорення. Госпітальна летальність склала 6,2\% (два пацієнти). В одному випадку причиною смерті була гостра серцева недостатність (ГСН), яка розвинулася в результаті малого серцевого викиду, в іншому - гостре порушення мозкового кровообігу внаслідок тромбоемболії судин головного мозку. Нелетальні ускладнення різноманітного характеру та важкості виявлені у 15 пацієнтів $(46,9 \%)$.

Частим госпітальним ускладненням після операцій з приводу IE на фоні ВВС була ГСН, яка відмічалась у трьох пацієнтів і вимагала інотропної підтримки. Причинами ГСН були важкий вихідний стан і наявність 
застійної серцевої недостатності, важка операція в умовах ШК і тривала ендогенна інтоксикація на фоні внутрішньосерцевої інфекції.

Типовим ускладненням раннього післяопераційного періоду була повна атріовентрикулярна блокада, яка потребувала імплантації штучного водія ритму серця (ШВРС). Це ускладнення відмічено у трьох хворих після протезування АК та репластики ДМШП. Гостре порушення мозкового кровообігу з геміпарезом діагностовано в одного пацієнта на сьомий день після операції, яке закінчилося повним відновленням рухової та чутливої функції протягом трьох тижнів. Причину даного ускладнення встановити не вдалось. Також серед ускладнень спостерігалися гідроторакс $(\mathrm{n}=2)$, нагноєння післяопераційної рани $(\mathrm{n}=1)$, парез діафрагми $(\mathrm{n}=1)$, реторакотомія $(\mathrm{n}=2)$, ексудативний перикардит $(\mathrm{n}=1)$, артеріальна емболія судин нижніх кінцівок $(\mathrm{n}=1)$.

Тривалість перебування в реанімаційному відділенні становила 3,9 1,6 діб (від 2 до 8 діб). Тривалість штучної вентиляції легень склала 26,5 $\pm 14,1$ год. (від 4 до 216 годин). Інотропна підтримка в більшості випадків була мінімальною. Тривалість перебування у відділенні склала 23,2士12,8 доби (від 7 до 39 діб). У ранньому післяопераційному періоді рецидиву внутрішньосерцевої інфекції не було виявлено. Всі пацієнти виписані зі стаціонару на фоні стійкої нормалізації температури та відсутності явищ інтоксикації з рекомендаціями продовжити антибактеріальну терапію протягом 4-6 тижнів.

Таким чином, пацієнти з ВBC, ускладненими IE, потребують ретельного спостереження в ранньому післяопераційному періоді для своєчасного виявлення ускладнень, корекція яких із застосуванням медикаментозних та інструментальних методів лікування в більшості випадків супроводжується хорошими результатами.

У віддалені строки після хірургічного втручання обстежено 28 пацієнтів - 93,3\% виписаних на госпітальному етапі. Із двома пацієнтами контакти втрачені. Період спостереження тривав від п'яти місяців до 10,1 років $(5,9 \pm 2,5$ років). Вік пацієнтів на момент обстеження варіював від 2,1 до 24,3 років $(17,1 \pm 7,8)$. За даними аналізу (Kaplan-Meier), показник кумулятивної виживаності хворих через 1 рік після операції склав $100 \%$, через 5 років $-96,2 \%$; через 10 років $-90,2 \%$ (рис. 1).

У віддаленому періоді померли два пацієнти $(7,1 \%)$. В одному випадку була виконана пластика ДМШП, але через рік після першої операції діагностовано рецидив IE 3 реканалізацією ДМШП. На ЕхоКГ виявлено частковий відрив латки та вегетації по краях дефекту. Причиною ускладнення була інфекція, спричинена Candida albicans. При обстеженні за даними

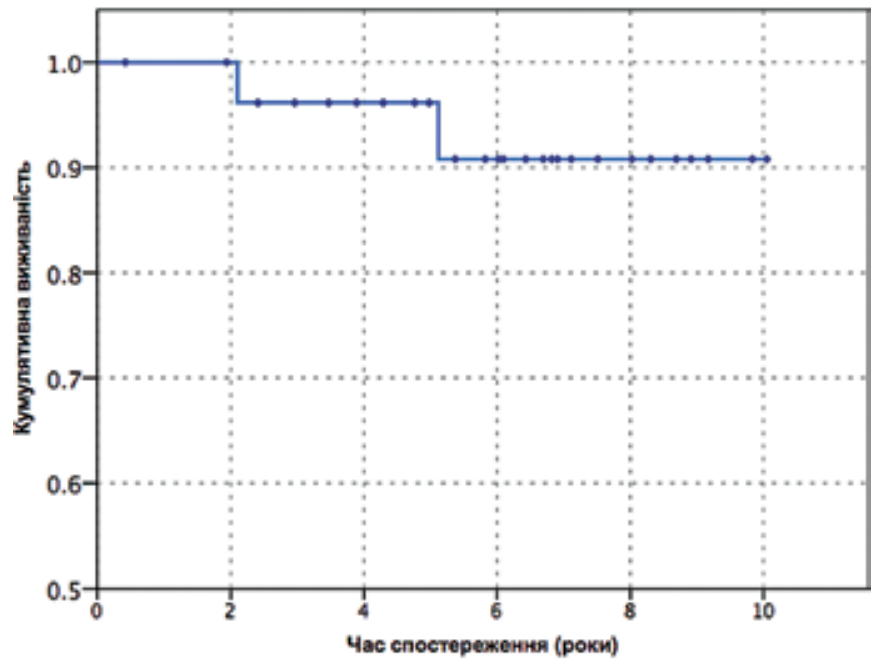

Рис. 1. Крива виживаності прооперованих хворих у віддаленому періоді спостереження

комп’ютерної томографії діагностовано множинні вогнища крововиливів та ішемії в головному мозку. Після виконання повторної пластики ДМШП із санацією порожнин серця на фоні протигрибкової та антибактеріальної терапії препаратами резерву вдалося досягти стійкої нормалізації стану хворої. Через рік після виписки пацієнтка померла в стаціонарі за місцем проживання внаслідок гострого порушення мозкового кровообігу. Від аутопсії батьки відмовилися.

У другого пацієнта, якому було виконано протезування АK з усуненням субаортального стенозу, видаленням вегетацій з АК та пластикою абсцесу кореня аорти аутоперикардіальною латкою, після операції було імплантовано ШВРС з ендокардіальним шлуночковим електродом. Причиною летального випадку було порушення роботи ШВРС через 5 років після операції.

Одним з найбільш типових віддалених післяопераційних ускладнень був рецидив IЕ, який виник у двох $(7,1 \%)$ пацієнтів. В одному випадку через 5 місяців після протезування АК розвинувся протезний ендокардит з формуванням парапротезної фістули, виконано репротезування АК. В іншому випадку рецидив IE виник через рік після пластики ДМШП. Причиною була інфекція, спричинена Candida albicans. Виконана репластика ДМШП, видалення вегетацій та санація камер серця.

Також слід відмітити, що у віддаленому періоді виконано три повторні оперативні втручання, не пов'язані з рецидивом IE. У першому випадку у хворого, якому була виконана пластика ДМШП і видалення вегетацій з ТК, через шість років після перенесеної операції сформувалася вада МK з вираженою регургітацією на клапані. Необхідно зазначити, що під час першої операції було виявлено пролапс МК з мінімальною регур- 


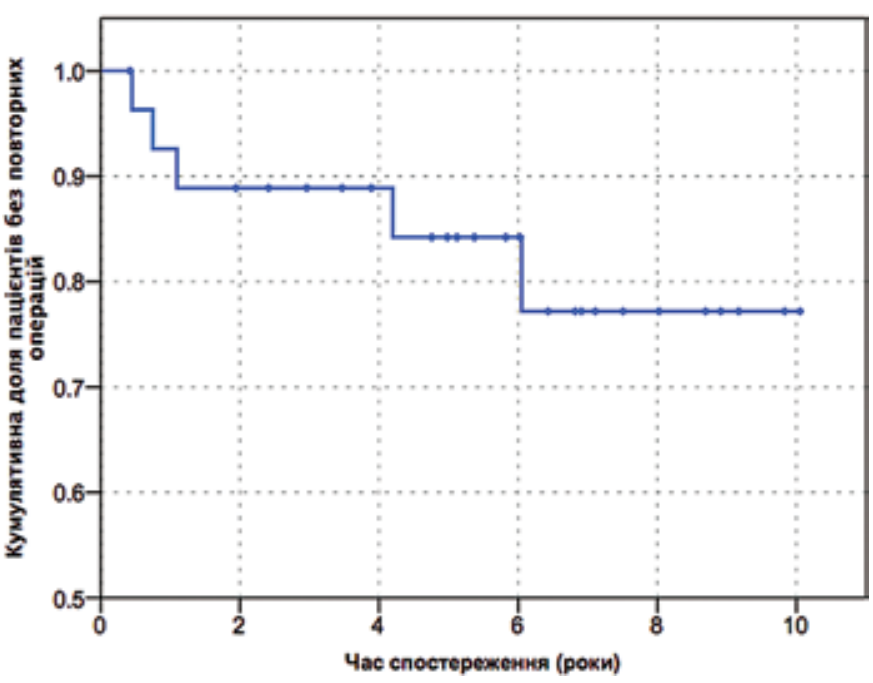

Рис. 2. Крива кумулятивної частки пацієнтів без повторних операцій у віддаленому періоді спостереження

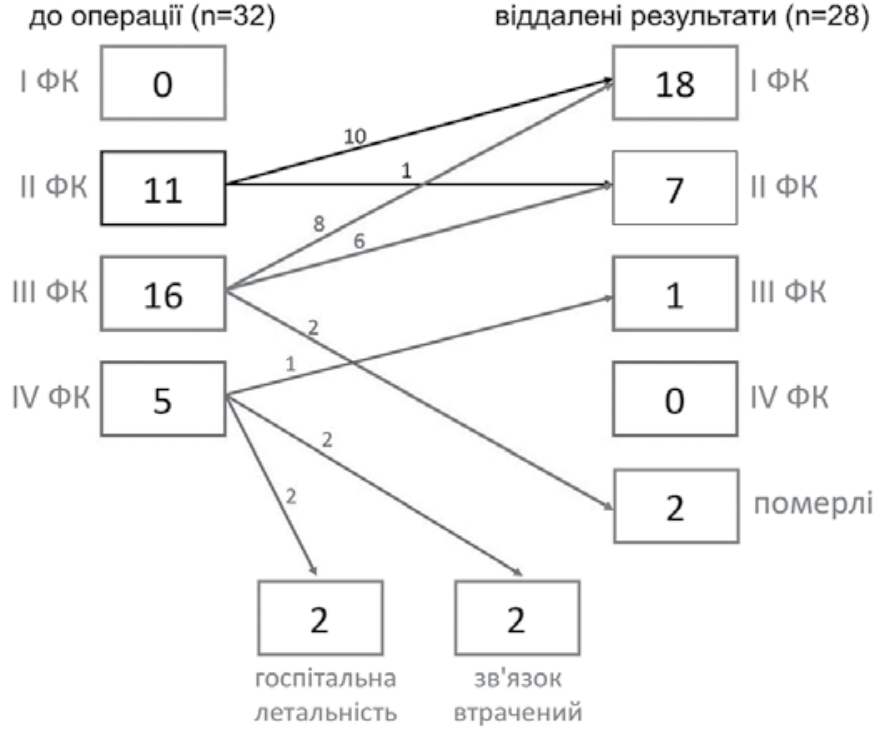

Рис. 3. Динаміка змін ФК стану хворих у віддаленому періоді після операції

BВC. При IE відбувається ушкодження клапанного апарату, погіршується скоротлива здатність міокарда з порушенням внутрішньосерцевої гемодинаміки. Не менш важливим чинником у патогенезі IE $\epsilon$ септична інтоксикація організму, емболізація органів септичними емболами з порушенням регіонального кровотоку, змінами в імунному статусі з проявом аутоімунних реакцій, що більш властиво для дитячого організму.

Ретроспективний аналіз етіології та клінічного перебігу IE показав значні зміни на сучасному етапі [2]. Захворювання стало частіше реєструватись у дітей раннього віку, збільшилася частота випадків після кардіохірургічних втручань. У 2012 р. опубліковані результати аналізу лікування дітей з IE в клініці Mayo Clinic за 60 років [13]. Автори відмічають, що основним первинним захворюванням залишаються BВC, але значно частіше ендокардит почав діагностуватися як первинне захворювання. Не змінився і інфекційний агент: як і раніше, перше місце посідає Staphylococcus aureus.

Наше дослідження також показало, що ранне хірургічне лікування не пов'язане з високим ризиком летального результату. В ранньому післяопераційному періоді померло два пацієнти, прооперовані на фоні важкої серцевої та поліорганної недостатності, що призвело до негативного результату.

Отримані добрі віддалені результати хірургічного лікування IE у дітей з ВBC продемонстрували ефективність активної хірургічної тактики. Своєчасно виконана операція сприяє зменшенню проявів серцевої недостатності та покращенню ФК за NYHA. Також важких ускладнень є IE, який часто супроводжує 
необхідно відмітити, що вибрана тактика лікування створює сприятливі передумови для доброї соціальної та трудової реабілітації у віддаленому періоді.

Таким чином, результат хірургічного лікування IE у дітей залежить від багатьох факторів, серед яких висока обізнаність педіатрів про ризик IE у дітей не тільки з ВВС, а також рання діагностика, які мають вирішальне значення для прогнозу захворювання та своєчасного хірургічного лікування.

Висновки. Раннє хірургічне втручання при IЕ у дітей iз ВВС є виправданим, адже супроводжується добрими показниками 5-річної $(96,2 \%)$ та 10 -річної $(90,2 \%)$ виживаності пацієнтів. При цьому частота рецидивів склала лише $7,1 \%$. Частота відсутності реоперацій через 5 років склала $84,2 \%$, а через 10 років - 77,2\%. Ці показники є також прийнятними, адже деякі $\mathrm{BBC}$ за відсутності IЕ потребують етапного лікування або супроводжуються високим ризиком повторного оперативного втручання. Вибрана нами тактика хірургічного лікування IЕ при ВBC супроводжується покращенням клінічного стану більшості пацієнтів, про що свідчить перехід у більш високий ФК за NYHА 96,1\% хворих.

\section{Література}

1. Characteristics of children hospitalized with infective endocarditis / Day M. D., Gauvreau K., Shulman S. et al. // Circulation. - 2009. - Vol. 119. - P. 865-70.

2. The changing epidemiology of pediatric endocarditis at a children's hospital over seven decades / Rosenthal L. B., Feja K. N., Levasseur S. M. et al. // Pediatr Cardiol. 2010. - Vol. 31. - P. 813-20.

3. Infective endocarditis in children: native valve preservation isnfrequently possible despite advanced clinical disease / E. J. Hickey, G. Jung, C. Manlhiot et al. // Eur J Cardiothorac Surg. - 2009. - Vol. 35. - P. 130-135.

4. Early predictors of in hospital death in infective endocarditis / Chu V. H., Cabell C. H., Benjamin D. K. Jr. et al. // Circulation. - 2004. - Vol. 109, № 14. - P. 1745-9.

5. 2017 AHA \ACC Focused Update of the AHA \ACC Guideline for the Management of patiens With Valvular Heart Disease: A Report of the American College of Cardiology / Nishimura R. A., Otto C. M., Bonow R. O. et al. // American Heart Assotiation Task Force on Clinical Practice Guidelines. Circulation 2017.

6. Infective Endocarditis in Children with Congenital Heart Disease. Cumulative incidence and predictors / Dinela Rushani, Jay S. Kaufman, Raluca lonescu-Ittu et al. // Circulation. - 2013. - Vol.128. - P. 1214-1419. Originally published September 23, 2013.

7. Incidence, predictors and mortality of Infective Endocarditis in adults with congenital heart disease without prosthetic valves / Darren Mylotte, MD, Dinela Rushani, MSc, Judith Therrien, MD, et al. // The American Journal of Cardiology. - December 15, 2017. - Vol. 120, Issue 12. - P. 2278-2283.

8. Infective endocarditis: diagnosis, antimicrobial therapy, and management of complications: a statement for healthcare professionals from the Committee on Rheumatic Fever, Endocarditis, and Kawasaki Disease, Council on Cardiovascular Disease in the Young, and the Councils on Clinical Cardiology, Stroke, and Cardiovascular Surgery and Anesthesia, American Heart Association: endorsed by the Infectious Diseases Society of America / Baddour L. M., Wilson W. R., Bayer A. S. et al. // Circulation. - 2005. Vol. 111. - P. e394-434.

9. Analysis of the impact of early surgery on in-hospital mortality of native valve endocarditis: use of propensity score and instrumental variable methods to adjust for treatmentselection bias / T. Lalani, C. H. Cabell, D. K. Benjamin et al. // Circulation. - 2010. - Vol. 121. - P. 1005-1013.

10. Early surgical therapy of infective endocarditis in children: A 15-year experience / Pirouz Shamszad, MD., Muhammad S., Khan, MD // The Journal of Thoracic and Cardiovascular Surgery. - 2013, September. - Vol. 146, Issue 3. - P. 506-511.

11. New criteria for diagnosis of infective endocarditis: utilization of specific echocardiographic findings. Duke Endocarditis Service / Durack D. T., Lukes A. S., Bright D.K. // Am J Med. - 1994. - Vol. 96. - P. 200-209.

12. Hoen B, Duval X. Clinical practice. Infective endocarditis // N Engl J Med. - 2013, Apr 11. - Vol. 368 (15). - P. 1425-33.

13. Infective endocarditis in the pediatric patient: a 60 -year single-institution review / Johnson J. A., Boyce T. G., Cetta F. et al. // Mayo Clin Proc. - 2012, Jul. - Vol. 87 (7). - P. 629-35.

\title{
Long-tearm follow-up after surgical treatment of infective endocarditis in children with congenital heart diseases
}

\author{
Prokopovych L., Golovenko O., Rudenko M., Spysarenko S., Malysheva T., Truba Y., Lazoryshynetz V.
}

National M. M. Amosov Institute of Cardiovascular Surgery National Academy of Medical Sciences of Ukraine (Kyiv)

The current work presents the experience of surgical treatment of infective endocarditis (IE) in children with congenital heart diseases (CHD). During the period from Jan 2010 to Dec 2017 in Amosov National Institute of Cardiovascular Surgery, 32 children with IE and CHD were operated. The mean age of patients at operation was $11,6 \pm 5,7$ years. Hospital mortality was $6,2 \%$ (2 patients).

A total of 28 (93.3\%) from 30 children who were discharged from the hospital were examined. The follow-up time was from five months to 10.1 years (5.9 \pm 2.5 years). The age of patients at the time of the examination varied from 2.1 to 24.3 years $(17.1 \pm 7.8$ years). There were two $(7,1 \%)$ late deaths. The cumulative survival rate of patients at one year after the op- 
eration was $100 \%, 5$ years $-96.2 \%, 10$ years $-90.2 \%$. In two (7.1\%) patients, signs of IE were re-discovered. The proportion of patients without reoperations in the long-term follow-up at one year after surgery was $92.6 \%, 84.2 \%$ - at 5 years, $77.2 \%$ - at 10 years.

Key words: infective endocarditis, congenital heart diseases, surgical treatment follow-up examination.

\title{
Отдаленные результаты хирургического лечения инфекционного эндокардита у детей с врожденными пороками сердца
}

\author{
Прокопович Л. М., Головенко А. С., Руденко М. Н., Списаренко С. П., Малышева Т. А., Труба Я. П., \\ Лазоришинец В.В.
}

ГУ «Национальный институт сердечно-сосудистой хирургии имени Н. М. Амосова НАМН» (Киев)

В работе представлен опыт хирургического лечения инфекционного эндокардита (ИЭ) у детей с врожденными пороками сердца (ВПС). За период с января 2010 по декабрь 2017 г. в ГУ «НИССХ имени Н. М. Амосова НАМН» было прооперировано 32 ребенка с ИЭ на фоне ВПС. Средний возраст больных составил 11,6土5,7 года. Госпитальная летальность составила 6,2\% (два пациента). В отдаленные сроки после хирургического вмешательства обследовано 28 пациентов, что составляет 93,3\% выписанных на госпитальном этапе. Период наблюдения длился

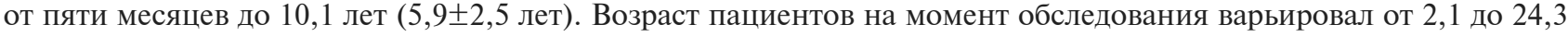
лет $(17,1 \pm 7,8)$. В отдаленном периоде умерли два пациента $(7,1 \%)$. По данным анализа, показатель кумулятивной выживаемости больных через год после операции составил 100\%, через 5 лет - 96,2\%, через 10 лет - 90,2\%. В двух $(7,1 \%)$ клинических случаях были повторно обнаружены признаки ИЭ. Показатель доли пациентов без повторных операций в отдаленном периоде наблюдения через 1 год составил 92,6\%, через 5 лет - 84,2\%, через 10 лет $-77,2 \%$.

Ключевые слова: инфекционный эндокардит, врожденные пороки сердиа, хирургическое лечение, отдаленные результаты. 